\title{
The Extent to Which Kindergarten Female Teachers in Jordan Practice the Skills of Developing the Educational Morals and Ethics System in Children According to Contemporary Educational Trends
}

\author{
Aida Deeb Mohammed ${ }^{1, *} \&$ Shaher Deeb Abu Shrakh ${ }^{2}$ \\ ${ }^{1}$ Curriculum Department, Faculty of Education, Jerash, Jordan \\ *Correspondence: Curriculum Department, Faculty of Education, Jerash, Jordan. E-mail: \\ draydahdeeb@yahoo.com
}

Received: August 12, 2018 Accepted: September 9, 2018 Published: December 15, 2018

doi:10.5296/ije.v10i4.13492ＵRL: https://doi.org/10.5296/ije.v10i4.13492

\begin{abstract}
The study aimed to identify the extent to which kindergarten teachers in Jordan practice the skills of developing the educational morals and ethics system in children according to contemporary educational trends. The study sample consisted of 71 female teachers who filled the questionnaire and 28 female teachers for observation purposes in Jerash for the academic year 2017/2018. The study followed the descriptive analytic methodology using the tools of questionnaire and observation. The study results showed that - from the point of view of the teachers - the highest practice is the affective emotional skill with a statistical average of 3.88. For the benefit of the private sector teachers, the most common skill according to the questionnaire paper is Cognition/Intellectual field with a percentage of $29.45 \%$.
\end{abstract}

Keywords: Kindergartens, Values and ethics, Jordan, Contemporary educational trends 


\section{Background and Importance of the Study}

Kindergarten is one of the most important educational institutions. It is the basic building unit that contributes to the development of society. Thus, kindergartens aim to rehabilitate the child properly and prepare him to get admission into school. The most important educational role of kindergarten is to build children's educational values and ethics in accordance with normal human instinct. Allah the Almighty says: "So direct your face toward the religion. inclining to truth. [Adhere to] the fitrah of Allah upon which He has created [all] people. No change should there be in the creation of Allah. That is the correct religion"-Ar-Room. 30.

The Ministry of Education in Jordan has taken care of the educational curricula that prepares the pupil or child starting from the kindergarten in the light of their educational goals in order to preserve their body, mind and religion, and to develop their moral values and human interaction within the society in accordance with the principles of proper education, high ethics, and positive behavior. All of this plays an important role in deepening the established morals and ethics system.

\subsection{Educational Activities of Morals and Ethics System}

Educational activities programs are the most important in identifying children trends, developing their talents, and fulfilling their needs (Lafi, 2010). This is because they contribute in developing the personality of the child and in improving their skills and performance (Salama et al., 2009), help the teachers to gain the desired trends (Al-Fahidi, 2009), promote cooperation and social integration (Abdelhamid, 2009), and reduce anxiety levels among children (Al-Bahnasawi \& Asal, 2008). Educational activities programs are one of the most important children activities in that they are concerned with the development of high values and ethics that is needed for the interactive curriculum of the kindergarten (Al-Atoum, 2008). This is because the curriculum in its large scope depends on the activities of the children and their participation (Al Yamani \& Ask, 2010). Hence, one of the important goals of educational activities programs is the upright bringing of children (Al-Mutairi, 2012). Therefore, in addition to inculcating educational values, the ethics and moral virtues, as well as the formation of a mentally, psychologically, socially, physically and morally balanced child should be put into consideration (Al Nahlawi, 2004). Another equally important factor is the nourishing of human emotions and adjusting their affections and emotions (Al Gawish, 2010). Furthermore, its role is apparent in shaping children's experiences and modifying their behavior and upbringing (Azzouz, 2010).

\subsection{Contemporary Educational Trends}

Kindergartens programs gained attention in the last two decades through educational projects supported by universities and centers for educational innovations such as IQEA for improving education quality (Hopkins, 1996) and the project supported by Keel and Wales universities in England for educators (Glover \& law. 1996). Thus, it is considered as an indicator of educational innovation and the cognitive and emotional reform which are developed during the early stages of childhood (Al Nemr, 2008).

Contemporary educational trends have emerged from the principles of pedagogical theories 
where Dollard and Miller developed a theory that depends on the principle of reinforcement (Miller \& Dollard, 1941). Here, internal or external motivation increases with reinforcement (Hill, 1990). Gestalt theory followed the laws of cognitive organization through children's learning by foresight (Wertheimer et al., 1992). The information processing model that stipulates that a child's mind deals with cognitive processes in a manner similar to what happens in the computers (Davis \& Palladion, 2004), and the systemic approach of Cognitive Psychology theories, arose trying to explain the child's cognitive behavior. The theory of constructivism is based on a philosophy that believes that the process of knowledge acquisition takes place through the modification of the child's cognitive structure. In the theory of advanced organizations, Ausubel emphasized that meaningful learning is the psychological basis for learning in children (Ausubel, 1968; Ausubel, 1978). The theory of the cognitive development highlighted the importance of children characteristics that enable them to adapt to and interact with the environment in which they live (Piaget, 1972; Berk, 2000). The theory of Brail Learning emerged indicating that knowing the nature of brain functions explains the human behavior of a child (Spears \& Wilson, 2005). Primack (1962) considers the need to determine the child's favorite behavioral patterns and to rank them according to their value and importance to be practiced in his activities (Al Zaghoul, 2010). Givon (1979) argued that children's programs should be encouraged through activities. Fröbel suggested an approach that considers the psychological orientation (Fröbel, 1900). The applications of social learning theory have been concerned with the role of observation, imitation, simulation, role playing and its importance for children (Bandura, Eysenck \& Eysenck, 1989). Expectancy Learning theory suggests that learning is linked to perceptions and expectations about the child's environment (Leahey, 1997).

\section{The Question of the Study}

Due to the contemporary educational trends, remarkable attention has been given to the desired behavioral patterns of the child. Thus, this is because there is a correlation between the children participation at early stages in extracurricular activities and their social and academic development as demonstrated in Martincevic (2010). Aweis (2009) showed an enhancement in the performance of the sample female teachers in developing some cognitive abilities for kindergarten children. Meanwhile, Hassan (2010) showed a decreased educational responsibility towards activating their educational values. This was despite the available opportunities for kindergarten teachers to instill educational values in children. Therefore, there is a need to determine the extent to which kindergarten teachers in Jordan practice the skills of developing the educational morals and ethics system in children according to contemporary educational trends. Therefore, this study sought to answer the following questions:

- What is the extent to which private and public Kindergarten female teachers in Jordan practice the skills of developing the educational morals and ethics system in children according to contemporary educational trends from their point of view? 
- Are there any statistically significant differences at the level of significance $(\mu \leq 05)$ between the extent to which private and public kindergarten female teachers in Jordan practice the skills of developing the educational morals and ethics system in children according to contemporary educational trends according to the questionnaire?

- What is the proposed scenario to develop the system of educational morals and ethics among Kindergarten children in the light of contemporary educational trends?

\subsection{The Aim of the Study}

The current study aims at identifying:

- The extent to which private and public Kindergarten female teachers in Jordan practice the skills of developing the educational morals and ethics system in children according to contemporary educational trends from their point of view;

- The statistically significant differences at the level of significance $(\mu \leq 05)$ between the extent to which private and public kindergarten female teachers in Jordan practice the skills of developing the educational morals and ethics system in children according to contemporary educational trends;

- The proposed scenario to develop the system of Islamic morals and ethics among children in the light of contemporary educational trends.

\subsection{Study Terms}

2.2.1 Conceptualization: A set of objectives, strategies, and systematic organizing procedures proposed by the study in the light of contemporary educational trends to develop the educational morals and ethics system among kindergarten children in Jerash, Jordan.

2.2.2 Kindergarten: Governmental and private educational institution accredited by the Ministry of Education, which includes children from the age of 4 to 6 years old to prepare them in the pre-school for the first semester 2017/2018 in Jerash, Jordan.

2.2.3 Kindergarten Female Teacher: A teacher with an educational qualification or any other qualifications to raise children in kindergartens in Jerash, Jordan, for the first semester 2016/2017.

2.2.4 Moralsand Ethics System: A collection of noble educational beliefs, moral principles, positive attitudes and humanitarian values acquired by the child through his interaction with the attitudes and experiences during his stay in kindergarten.

\subsection{Study Boundaries}

The study is limited by the objective of studying the extent to which private and public 
kindergarten female teachers in Jordan practice the skills of developing the educational morals and ethics system in children according to contemporary educational trends. It also aims to propose a scenario to develop the system of educational morals and ethics among children in the light of contemporary educational trends. This includes the area of Jaresh and its suburbs, and the time during the first semester of the academic year of 2016/2017 AD.

\subsection{Study Population and Its Sample}

The study population consists of all kindergarten female teachers in the city of Jerash and its suburbs for the academic year 2017/2018 totaling at 89 teachers. Study sample was selected by random stratified method. The sample consisted of 71 teachers who filled questionnaire, as well as 28 teachers who were involved for observation purposes.

\subsection{Study Tools}

2.5.1 Validity and Consistency of the Questionnaire: The questionnaire in its first form included 49 items distributed over 5 sections. To verify the validity of the questionnaire, it was presented to $13 \mathrm{PhD}$ degree holders in the specialties of kindergarten, educational psychology, measurement and evaluation, educational supervision, Islamic education, and curricula and methods of teaching. After considering their feedback on the integrity of the paragraphs and their relevance to their sections, the number of the paragraphs of the questionnaire in its final form became 40 divided over 5 sections. The consistency factor was tested by applying the questionnaire to a sample of 53 kindergarten teachers other than the study sample. The questionnaire was then re-applied to the same sample after 14 days. Consistency factor was found to be 850 , which is acceptable for the purpose of the study.

2.5.2 Validity and Consistency of Direct Observation: The observation card is designed in accordance with the sections of the questionnaire, and then the results of the observation card are interpreted by a numerical estimation scale similar to the questionnaire according to the following criteria:

- Always: If the teacher practiced the skill four or more times during the three observation sessions.

- Often: If the teacher practiced the skill three times during the observation sessions.

- Sometimes: If the teacher practiced the skill twice during the observation sessions.

- Rarely: If the teacher practiced the skill once during observation sessions.

- Never: If the skill was never exercised during observation sessions.

The observation card has been modified in light of the suggestions of the arbitrators and their directions. The observation card in its final form consists of 40 paragraphs distributed over 5 sections. Each section had 8 paragraphs. The card consistency was determined by observing 15 teachers in kindergarten by the researcher and another three observers. The similarity 
between them was $87.69 \%$. The researcher used the help of two researchers with master's degrees in teaching after training them on the application of study tools and its interpretation under the supervision of the researcher.

\section{Statistical Analysis}

The study used mean, standard deviations, the relative weight of each paragraph of the questionnaire as shown in Table 1. Also, the percentages are shown in the observation card in Table 2.

\section{Research Methodology}

In this study we identified the extent to which kindergarten teachers in Jordan practice the skills of developing the educational morals and ethics system in children according to contemporary educational trends. In doing that, we used a descriptive analytical method through the use of questionnaire and observations. More specifically, this study aimed at looking into the extent of conformity to the contemporary educational trends as the female kindergarten teachers develop the children.

Three main research questions guided the study are namely: (1) What is the extent to which private and public Kindergarten female teachers in Jordan practice the skills of developing the educational morals and ethics system in children according to contemporary educational trends from their point of view? (2) Are there any statistically significant differences at the level of significance $(\mu \leq 05)$ between the extent to which private and public kindergarten female teachers in Jordan practice the skills of developing the educational morals and ethics system in children according to contemporary educational trends according to the questionnaire? (3) What is the proposed scenario to develop the system of educational morals and ethics among Kindergarten children in the light of contemporary educational trends?

The study was carried out in the city of Jerash and its suburbs in the 2016/2017 academic session. And out of the 89 female teachers of the population, a sample size of 71 female teachers, who filled the questionnaire, and 28 others, for observation purposes, were selected through random stratified method.

In determining the extent of conformity to contemporary trends, the observations of the study were based on the point of view of the teachers. Therefore, as have been identified, the highest practice is the affective emotional skill with a statistical average of 3.88. For the benefit of the private sector teachers, the most common skill according to the questionnaire paper is Cognition/Intellectual field with a percentage of $29.45 \%$. 


\section{Previous Studies}

Any follower of pedagogical studies of kindergartens would find a lack in the studies that seek to develop the educational morals and ethics systems among children in Jordan in the light of the contemporary educational trends. Thus, the researcher has studied the previous studies related to the subject of his study. Among them are the following:

Hassan (2010) study aimed to identify the reality of the educational values of kindergarten children in Egypt in the light of contemporary social changes. The study sample consisted of 109 female teachers, managers, and supervisors from 23 private, governmental, and experimental kindergartens. The study concluded that many kindergarten managers are not qualified to work in kindergartens. The study stated that there is little interest in activating educational values among preschool children, and that opportunities are available for private kindergartens to instill educational values in children.

Martincevic (2010) study aimed to identify the impact of extracurricular activities during free time on the academic and personal development of the primary school students. The study sample consisted of 816 primary school students in the city of Croatia using observation approach and the tools of observation and survey. The results of the study showed a correlation between the participation of primary school students in extracurricular activities and their social and academic development.

Aweys (2009) study aimed to identify a program to train kindergarten teachers to develop some thinking skills among Kindergarten children by proposing a program to train kindergarten teachers and a note card to monitor their performance. The sample included 199 children along with the participation of the teachers. The study results showed the performance of the sample teachers in improving the development of some thinking skills among Kindergarten children.

Al Jafary (2008) study aimed at identifying the role of teaching through stories in Islam and its applications in kindergartens, proposing a concept for its applications in kindergarten stage. The study used the descriptive approach. The study showed that the educational story is one of the most successful educational methods in achieving the goals of Islamic education in Kindergartens.

\subsection{Summary of Previous Studies}

The previous studies have variable goals due to their different purposes. Hassan (2010) study aimed to identify the reality of the educational values of kindergarten children in Egypt in the light of contemporary social changes. Al Jafary (2008) study aimed at identifying the role of teaching through stories in Islam and its applications in kindergartens. Aweys (2009) aimed to identify a program to train kindergarten teachers to develop some thinking skills among Kindergarten children, while Martincevic (2010) study aimed to identify the impact of extracurricular activities during free time on the academic and personal development of the primary school students. Hassan study used the analytical methodology while Jafary and Martincevic studies used the descriptive methodology. The current study is aimed at finding the extent to which kindergarten teachers in Jordan practice the skills of developing the 
educational morals and ethics system in children according to contemporary educational trends.

\section{Study Results and Discussions}

To answer the first question, "What is the extent to which private and public Kindergarten female teachers in Jordan practice the skills of developing the educational morals and ethics system in children according to contemporary educational trends from their point of view?", we calculated the mean, standard deviations, and relative weight of each paragraph out of the questionnaire as shown in Table 1.

Table 1. Questionnaire Paragraph Showing the Mean, Standard Deviation, and Relative Weight of Public and Private Sector Teachers

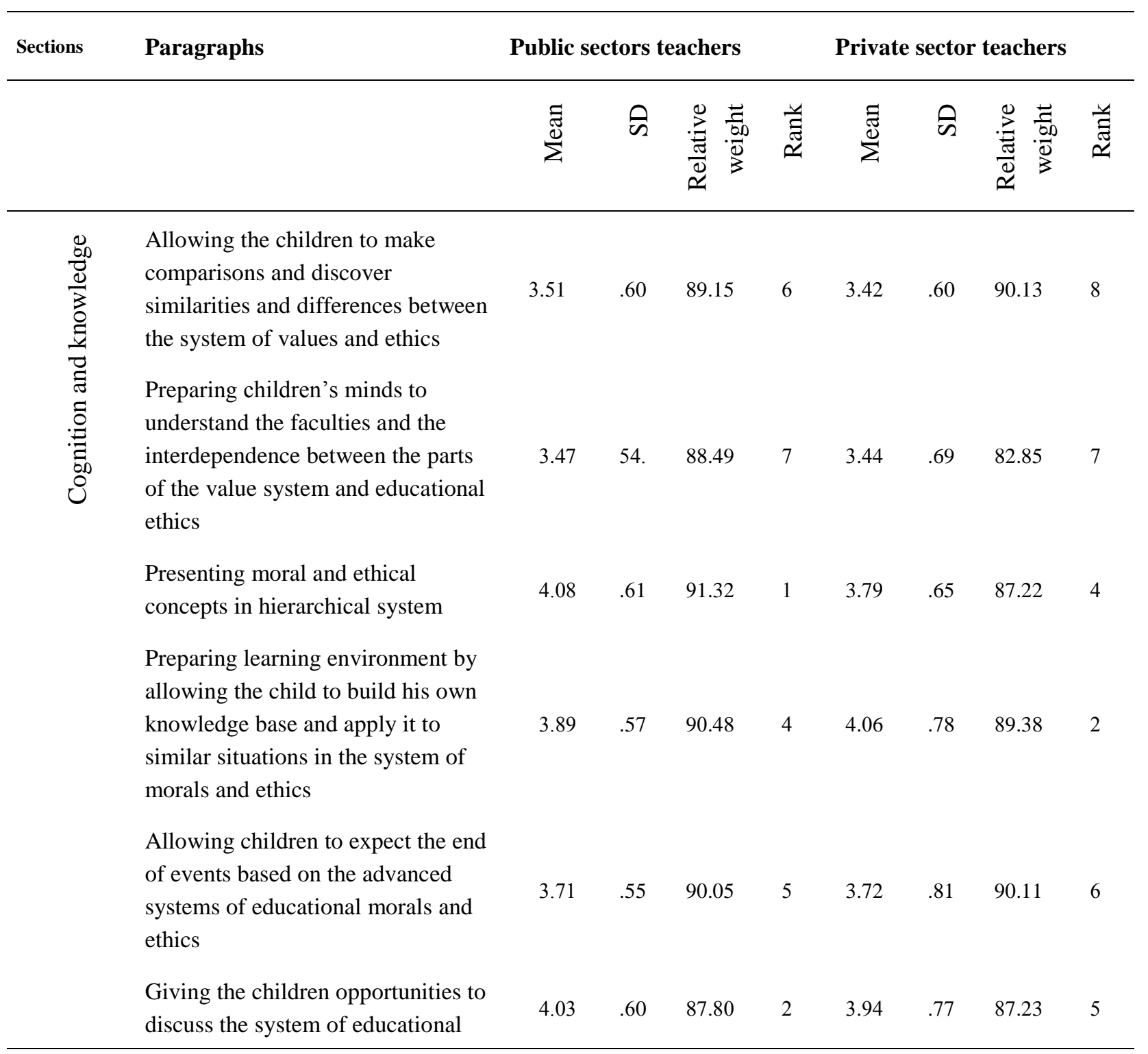


morals and ethics

Integrating knowledge and moral skills into the familiar cognitive fabric of children

Linking cognitive activities related to educational morals and ethics to some cognitive concepts with emotional images

\section{The whole section}

The participation of the teacher in the exercise of moral activities and the celebration of educational events with children

Creating social attitudes for children that allow them to discover educational morals and ethics

Helping children to adapt to their peers according to the system of educational morals and ethics

Developing children's sense of educational morals and ethics

Training children to take responsibility in practicing and applying educational morals and ethics system.

Developing social communication skills, allowing children to identify habits and values that has educational relevance to others.

Helping children to form social and educational relationships with their peers in the light of educational morals and ethics system

Establishing values, morals, ethics and social rules for the children

\section{The whole section}

\& educational morals and ethics

$\begin{array}{llllllll}3.13 & .59 & 85.14 & 8 & 3.94 & .82 & 90.10 & 3\end{array}$

$\begin{array}{llllllll}3.98 & .70 & 90.11 & 3 & 4.13 & .80 & 87.45 & 1\end{array}$

$\begin{array}{lllllll}3.75 & .60 & 89.06 & - & 3.78 & .74 & 88.05\end{array}$

$\begin{array}{llllllll}4.20 & .62 & 70.85 & 1 & 4.15 & .68 & 89.42 & 1\end{array}$

$\begin{array}{llllllll}3.00 & .65 & 91.60 & 8 & 3.86 & .70 & 76.02 & 3\end{array}$

$\begin{array}{llllllll}3.52 & .68 & 90.47 & 4 & 3.60 & .73 & 85.10 & 5\end{array}$

$\begin{array}{llllllll}3.53 & .60 & 80.61 & 3 & 3.63 & .82 & 82.48 & 4\end{array}$

$\begin{array}{llllllll}3.90 & .59 & 91.23 & 2 & 4.10 & .86 & 86.24 & 2\end{array}$

$\begin{array}{llllllll}3.42 & .63 & 79.80 & 6 & 3.51 & .82 & 85.09 & 7\end{array}$

$\begin{array}{llllllll}3.38 & .69 & 88.39 & 5 & 3.31 & .80 & 90.05 & 6\end{array}$

$\begin{array}{llllllll}3.49 & .65 & 91.60 & 5 & 3.58 & .76 & 86.72 & 6 \\ 3.60 & .63 & 85.60 & - & 3.71 & .77 & 85.14 & - \\ 3.77 & .58 & 94.89 & 4 & 3.85 & .71 & 92.58 & 4\end{array}$


Providing a safe psychological atmosphere for children while learning the educational morals and

.61

90.32

4.14

.69

$93.84 \quad 2$

ethics system

Teaching children to express their feelings and emotions in the light of the educational morals and ethics system

Raising the interest of children to participate in educational activities programs with moral and ethical dimensions

Developing positive attitudes of children towards the educational morals and ethics system

Helping children to get fully involved in practicing educational morals and ethics system

Listening to songs about morals and ethics

$\begin{array}{llllllll}4.10 & .68 & 87.41 & 2 & 4.15 & .68 & 89.38 & 1\end{array}$

320

Presenting various educational models and memorable incidents from the lives of reformers and educators to follow them

\section{The whole section}

.59

Putting the child in situations related to affective experience and daily practice of moral and ethical activities

Guiding children and helping them to discover their moral and ethical skills and tendencies and working on their development

$\begin{array}{llllllll}3.52 & .67 & 86.65 & 5 & 3.69 & .76 & 85.46 & 5\end{array}$

Developing the motor skills of children based on their common sense to acquire skills and valuable moral and living experiences.

Repeating performance behaviors that has educational moralsfor children and focusing on them

$\begin{array}{llllllll}3.11 & .59 & 85.62 & 8 & 3.10 & .80 & 90.30 & 8\end{array}$


Private sector teachers

Developing children's initiative to participate in activity programs with $\begin{array}{llllllll}3.49 & .50 & 77.17 & 6 & 3.60 & .81 & 86.24 & 6\end{array}$ moral with ethical implications.

Memorizing some educational sayings and poetry related to children's moral experience

Raising children's interest in moraland ethical activities.

Training children to do their work with sincerity and honesty

\section{The whole section}

Developing children's sense of Allah's great gifts to them

Teaching children to practice some educational moral and ethical activities in a social environment

Empowering ethical and moral virtues in children

$\begin{array}{lllllllll}3.54 & .57 & 91.84 & 4 & 4.15 & .67 & 91.62 & 2 \\ & & & & & & & \\ 4.18 & .61 & 92.41 & 2 & 4.10 & .88 & 93.15 & 4 \\ & & & & & & & \\ 3.46 & .70 & 81.60 & 7 & 3.54 & .81 & 79.39 & 7 \\ 3.73 & .60 & 86.84 & - & 3.84 & .75 & 88.53 & - \\ 3.14 & .81 & 88.35 & 8 & 4.19 & .95 & 91.82 & 2 \\ & & & & & & & \\ & & & & & & & & \\ 4.11 & .72 & 95.31 & 2 & 4.45 & .79 & 93.59 & 1 \\ & & & & & & & \end{array}$

$\begin{array}{llllllll}3.33 & .64 & 91.32 & 6 & 3.34 & .70 & 80.20 & 8\end{array}$

Presenting figurative stories with educational goals to consolidate educational values and morals among children

Teaching children to listen to verses from the Holy Quran with great attention

Modifying children behavior according to educational morals

.54

Strengthening children's sense of faith through the development of spiritual aspects while participating in educational activities programs

Reinforcing children's practice of moral and ethical activities during their participation in educational

$\begin{array}{llllllll}3.58 & .60 & 85.42 & 3 & 3.40 & .84 & 87.81 & 7\end{array}$
activity programs

The whole section

$\begin{array}{llllllll}3.60 & .66 & 89.01 & - & 3.69 & .80 & 87.77 & - \\ 3.68 & .62 & 87.66 & - & 3.78 & .75 & 86.75 & -\end{array}$




\section{Mll Macrothink}

International Journal of Education ISSN 1948-5476 2018, Vol. 10, No. 4

Table 1 shows that the mean level of the public and private kindergarten teachers practice for the skills of developing educational morals and ethics system for children, from their point of view, is 3.73. The highest paragraph for government sector teachers in the section of cognition and knowledge was "Presenting moral and ethical concepts in hierarchical system" with a mean of 4.08, standard deviation of 0.61 , and relative weight of 91.32 . This may be due to the ease of transition from the public to the private and from the known to the unknown according to the principles of teaching and learning. The highest paragraph for the category of private sector teachers in the field of cognition and knowledge was "Linking cognitive activities related to educational morals and ethics to some cognitive concepts with emotional images" with a mean of 4.13 , Standard deviation of 0.80 and relative weight of 89.42. This may be attributed to the private sector care for providing many educational tools to aid the learning process, in order to improve and develop the educational process within the kindergarten to improve their competitiveness in the informal education market. This result is somewhat consistent with Hassan's 2010 study that concluded that kindergartens in the private sector have more opportunities than kindergartens in the governmental sector in instilling and developing educational morals and ethics.

Both public and private sectors teachers responded in the same way to the sections of the study tools. The highest paragraphs of the social interaction section were "The participation of the teacher in the exercise of moral activities and the celebration of educational events with children" with a mean, standard deviation and relative weight $(4.20,0.62,70.85)(4.15$, $0.68,89.42)$ for the teachers in the public and private sectors, respectively. This may be due to the teachers' belief that their participation in the activities and celebrations with children stresses on the importance of these activities, moves them out of the self-centered spot into a circle of collaborative action, and collective celebration at events.

The highest paragraph for government sector teachers in the section of Emotions was "Presenting various educational models and memorable incidents from the lives of reformers and educators to follow them" with a mean of 4.20 , standard deviation of 0.51 , and relative weight of 80.47. This may be attributed to the keenness of teachers to develop the children's abilities to follow variable simulation of models, in accordance with their aspirations in the light of their family and social development. This is in addition to developing reflective aspects in children. The highest paragraph for the category of private sector teachers in the field of cognition and knowledge was "Teaching children to express their feelings and emotions in the light of the educational morals and ethics system" with a mean of 4.15 , Standard deviation of 0.68 , and relative weight of 89.38 . This may be due to the teachers' keenness to consolidate different concepts in children with disciplined and balanced emotional behavior and to enable them to express their emotions to their families to attract their attention by kindergarten activities.

Both public and private sectors teachers responded in the same way to the paragraph of "Putting the child in situations related to affective experience and daily practice of moral and ethical activities" in the physical sector with a mean of 4.42 and 4.45, standard deviation of 0.59 and 0.54 , and relative weight of 91.80 and 90.63 for the teachers in the public and 
private sectors, respectively. This may be due to teachers' conviction that knowledge should be applied to life situations in order to be established in children's mind and practice.

Table 1 shows as well that the highest paragraph for government sector teachers in the section of Faith and belief was "Presenting figurative stories with educational goals to consolidate educational values and morals among children" with a mean of 4.46, standard deviation of 0.62 , and relative weight of 87.57 . This is due to the variability of stories, their subjects, and their presentation which is the best technique to establish faith in children. This result reinforces the study of Jafry (2008) that concluded that teaching by stories is one of the most successful educational techniques to achieve the objectives of Islamic education and its religious activities in kindergartens. The highest paragraph for the category of private sector teachers in the field of cognition and knowledge was "Teaching children to practice some educational moral and ethical activities in a social environment" with a mean of 4.45, Standard deviation of 0.79 , and relative weight of 93.59 . This may be due to the keenness of the private sector on celebrating some moral events such as: Mother's Day, Teacher's Day, and in a social environment in which children, mothers, and teachers participate.

Table 1 shows as well that the highest section for government sector teachers is cognition and knowledge, with a mean of 3.75, standard deviation of 0.60 , and relative weight of 89.06 . This may be attributed to the interest of government sector teachers in providing children with enough knowledge in order to get positive reports from their supervisor and for the director of the kindergarten to get promoted. The highest section of private sector teachers is emotions, with a mean of 3.88, Standard deviation of 0.69 , and relative weight of 84.27 . This may be attributed to the keenness of private sector teachers to attract children to kindergartens, which encourages the parents to fulfill the wishes of their children and to continue to send them to the same kindergarten and teachers. This establishes the teachers' position in the kindergarten for a longer period of time. Also, this aligns with the results of Hassan's (2010) study; kindergartens in the private sector have better opportunity to instill educational morals in children.

To answer the second question, "Are there any statistically significant differences at the level of significance $(\mu \leq 05)$ between the extent to which private and public kindergarten female teachers in Jordan practice the skills of developing the educational morals and ethics system in children according to contemporary educational trends according to the questionnaire?", we calculated the max score for the extent to which kindergarten teachers in Jordan practice the skills of developing the educational morals and ethics system in children according to contemporary educational trends. The number of the paragraphs is 40 and the scale of measuring the observations is quintuple scale. So, the max score is $40 \times 5=200$. The extent to which the female teachers practiced the skills judging by the total score of the card is 129 out of 200 with a percentage of $64.5 \%$ (calculated by the equation $129 / 200 \times 100=$ 64.5 ), which falls under the required percentage of $80 \%$. The distribution of practice levels over the different sectors came as follows: 
Table 2. Distribution of Kindergarten Teacher Practice of the Skills of Developing Educational Morals and Ethics System as Shown in Observation Cards

\begin{tabular}{|c|c|c|c|c|c|c|c|c|c|c|c|c|c|}
\hline \multirow{3}{*}{ 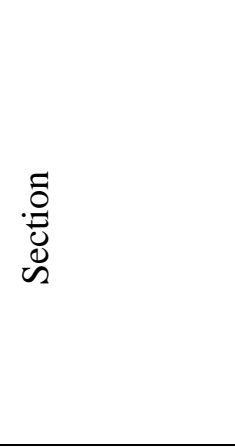 } & \multirow{3}{*}{ 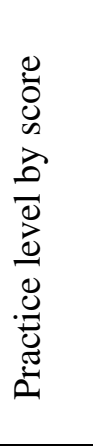 } & \multirow{3}{*}{ 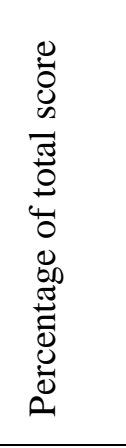 } & \multirow{3}{*}{ 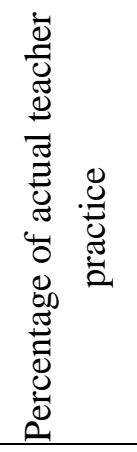 } & \multicolumn{10}{|c|}{ Distributing practice level over quintuple } \\
\hline & & & & \multicolumn{2}{|c|}{ always } & \multicolumn{2}{|c|}{ often } & \multicolumn{2}{|c|}{ Sometimes } & \multicolumn{2}{|c|}{ rare } & \multicolumn{2}{|c|}{ Never } \\
\hline & & & & 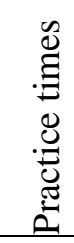 & $\begin{array}{l}0 \\
\stackrel{0}{0} \\
\ddot{n}\end{array}$ & 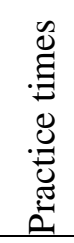 & 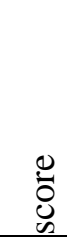 & 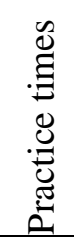 & 苛 & 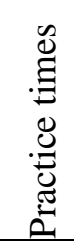 & D. & 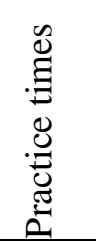 & 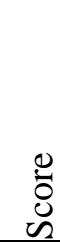 \\
\hline $\begin{array}{l}\text { Cognition and } \\
\text { knowledge }\end{array}$ & (38) & $19 \%$ & $29.45 \%$ & 2 & 10 & 4 & 12 & 5 & 10 & 6 & 6 & *2- & 0 \\
\hline $\begin{array}{l}\text { Social } \\
\text { interaction }\end{array}$ & $(26)$ & $13 \%$ & $20.15 \%$ & 1 & 5 & 3 & 9 & 4 & 8 & 4 & 4 & *4- & 0 \\
\hline Emotions & (34) & $17 \%$ & $26.35 \%$ & 2 & 10 & 4 & 12 & 4 & 8 & 4 & 4 & *3- & 0 \\
\hline $\begin{array}{l}\text { Physical } \\
\text { performance }\end{array}$ & (31) & $15,5 \%$ & $2 ., 03 \%$ & 2 & 10 & 4 & 12 & 2 & 4 & 5 & 5 & *5- & 0 \\
\hline $\begin{array}{l}\text { Faith and } \\
\text { belief }\end{array}$ & (34) & $17 \%$ & $26.35 \%$ & 2 & 10 & 4 & 12 & 4 & 8 & 4 & 4 & *3- & 0 \\
\hline
\end{tabular}

*- lack of practice

Table 2 shows that most of the most sought practices of kindergarten teachers to develop educational morals and ethics system among kindergarten children is the section of cognition and knowledge, with a percentage of $19 \%$ of the maximum score and $29.45 \%$ of the actual practice. This may be attributed to the teachers' keenness to provide children with a system of educational morals and ethics with sufficient cognitive aspects in order to practice it in their natural life situations. This result is consistent with the government sector teacher's practices, which is the highest in the section cognition, as explained in Table 1. This result is also consistent with Martincevic (2010) study that concluded based on a relation between the involvement of children in extracurricular activities and the academic scores of children.

To answer the third question, "What is the proposed scenario to develop the system of educational morals and ethics among Kindergarten children in the light of contemporary educational trends?", the researcher analyzed the extent to which kindergarten teachers in Jordan practice the skills of developing the educational morals and ethics system in children according contemporary educational trends and found an evident lack in it. The result of the study corresponds with the pedagogical studies of Hassan (2010), Martincevic (2010), Aweys (2009), and Al Jafary (2008) on how kindergartens teachers seek to develop the educational morals and ethics systems among children in the light of the contemporary educational trends. 


\subsection{Proposed Scenarios}

- kindergarten is the most important educational stage in the upbringing of children and the progress of humanity.

- Kindergarten teachers are the main element in developing educational morals and ethics system among Kindergarten children.

- Attention to contemporary educational trends contribute to enriching the programs of activities related to the development of educational morals and ethics system among kindergarten children and improve the performance of their teachers.

\subsection{Goals and Objectives}

- Formulating a new vision for the development of educational morals and ethics system among Kindergarten children in the light of contemporary educational trends with the contributions of all academic and educational institutions.

- Provide kindergartens teachers with the knowledge and skills and trends of contemporary education necessary for the development of educational morals and ethics system in kindergarten in Jordan.

\subsection{Implementation}

- Coordination with the Ministry of Education, Directorate of Supervision and Educational Training to support the proposed scenario.

- Providing human resources; high efficiency supervisors and kindergarten principals, in addition to material requirements such as of classrooms and theaters of activities.

- Identifying the areas that needs training for kindergarten teachers to develop the educational morals and ethics system among Kindergarten children.

- Getting educational experts and kindergartens specialists in the field of morals and ethics systems and educational cooperation with civil society institutions.

\subsection{The Content of the Proposed Scenario}

The content of the proposed scenario includes the following fields:

1- Academic preparation and vocational qualification in universities, through the following procedures:

- Introducing specialized courses in modern pedagogical theories and contemporary trends in kindergarten.

- Introduce specialized courses in the educational morals and ethics system suitable for children.

- Making creative projects to develop the activities of kindergarten programs in the light of contemporary educational trends as a compulsory requirement for graduation from the Department of kindergarten. 
- Strengthening the educational morals and ethics system among female kindergarten students.

- Increasing hours of practical training from 12 field hours to 18 field hours.

2. Educational supervision and kindergartens management, through the following roles:

- Granting bonuses and incentives to teachers that excel in the preparation and implementation of the activities of the educational morals and ethics system.

- Attracting outstanding competencies to work in kindergartens.

- Localization of educational supervision in kindergartens to develop programs of educational morals and ethics system.

3. Kindergarten female teachers: Strengthening the roles and responsibilities required for the programs of developing the educational morals and ethics system, and these responsibilities are:

- To ensure academic and professional growth in the field of kindergarten specialization.

- The teacher's attention to her behavior and emotions as a role model for children in the light of the educational morals and ethics system.

- Belonging to the work in kindergartens and showing positive attitude towards the sanctity of the teaching profession.

- Strengthening human relations and exchanging of classroom visits and practical experiences among kindergarten teachers.

4. Educational programs and activities, which is as follows:

- Exploiting educational technology in the educational morals and ethics system.

- Diversifying teaching strategies and implementations of educational activities according to modern educational theories and trends.

- Paying attention to the practical applications of educational morals and ethics system in all programs and activities for kindergartens.

- Holding educational competitions for children on ethical and moral concepts and granting the winners certificates of appreciation and incentive.

5. Auditing the programs of development of educational morals and ethics system. among the evaluation strategies and tools are:

- Evaluation by observation and interview, oral and projection tests, dialogue, discussion, verbal and numerical appreciation ladders, monitoring / deletion lists, learning progress log, and narrative record. 
- Analysis of children's drawings and movements during their exercise of educational activities to evaluate the reality of their practice of the content of the programs of educational morals and ethics system.

\subsection{Evaluating the Proposed Scenario}

To determine the outcomes of the proposed scenario, it needs to be adjusted according to the following tools:

- A questionnaire to measure the trends of preschool teachers before and after the implementation of the proposed scenario.

- A questionnaire to measure the attitudes of educational supervisors and headteachers based on the proposed scenario.

- Observation card in which the observer writes down and monitors the behaviors of the target group of teachers during the training for all employees involved in the implementation of the program.

- Observation card to monitor the behaviors of the target group of teachers after training and at their work locations to determine the extent to which kindergarten teachers practice the skills of developing the educational morals and ethics system in children in light of the proposed scenario.

- Preparing records to follow up the kindergarten teachers' performance by educational supervisors and principals of kindergartens in the light of contemporary educational trends for the development of educational morals and ethics system.

\section{Recommendations}

In light of the results of the study, the two researchers recommend the following:

- Implementing of the proposed scenario by the Ministry of Education in Jordan to develop the educational morals and ethics system among kindergarten children.

- Holding specialized and advanced training courses for kindergarten teachers to train them with modern strategies of developing the educational morals and ethics system of preschool children and implementing them according to educational theories and contemporary trends.

- Enhancing the creativeness of kindergarten teachers with certificates and honorary awards to promote the development of Islamic ethics values and among kindergarten children.

\section{References}

Abdul Hamid, Alaa. (2009). School Activities. Dar Al Yazuri, Jerash.

Al - Jawish, Mohammed Ismail. (2010). Basics in Educational Activities. Horus Foundation, 
Alexandria.

Al Yamani, Abdul Karim \& Askar, Alaa. (2010). General Teaching Methods. Dar Zamzam, Jerash.

Al-Atom, Munther Sameh. (2008). Contemporary School Activity between Theory and Practice. Dar Al-Manahej, Jerash.

Al-Banhasawi, Abdul Raouf \& Asal, Khaled. (2008). Educational activities and the development of the educational process. Dar Al-Elam Wal-Eman, Cairo.

Al-Fahidi, Rashid Rasheed. (2009). Guide to school activities. Malek for information services, Kuwait.

Al-Mutairi, Abdul Latif. (2012). The extent of applying student activities accompanying the curriculum at middle school from the point of view of teachers and their relation to the achievement of their students in Kuwaiti schools, unpublished master's thesis, Faculty of Educational Sciences, Middle East University, Jordan.

Al-Nemr, Essam. (2008). Audition and Evaluation in Special Education. Dar Al-Yazuri, Jerash.

Al-Zoghoul, Emad Abdel Rahim. (2010). Theories of Learning. Dar Al Shorouk, Jerash.

Ausubel, D. (1978). In defense of advance organizers: A reply to the critics. Review of Educational Research, 48, 251-257. https://doi.org/10.3102/00346543048002251

Ausubel, D.P. (1968). Educational Psychology: A Cognitive View. New York: Holt, Rinehart \& Winston.

Azzouz, Refaat. (2010). Educational Activities. Tiba Foundation, Cairo.

Bandura, A. (1989). Human Agency in Social Cognitive Theory. American Psychologist, 44, 1175-1184. https://doi.org/10.1037/0003-066X.44.9.1175

Berk, L. (2000). Child development (5th ed.). Allyn \& Bacon.

Davis, S.F., \&Palladion, J.J. (2004). Psychology (4th ed.). Printice Hall, Inc.

Eysenck, H., \& Eysenck, S. (1976). Psychoticism as Adimension of personality. London: Hadder \& Stoughton.

Fröbel, Friedrich. (1900). The Student's Froebel: adapted from "Die Erziehung der Menschheit" of F. Froebel, by William H. Herford. 2 vols. London: Isbister, 1900-01. pt. 1 .

Givon, T. (1979). On Understanding Grammar. New York Academic Press.

Glover, D., \& law, S. (1996). Managing Professionol Development Education. London, Kogan.

Hassan, Samah. (2010). A proposal to activate some of the morals of kindergarten children in 
Egypt, Master Thesis unpublished, Faculty of Education, Helwan University, Egypt.

Hill, W. F. (1990). Learning: A survey of psychological interpretations (4th ed.). Harper Collins Publishers.

Hopkins, D., et al. (1996). Improving the quality of Education for All. London, David Fulton Publishers.

Jafri, Hana'a Bint Hashim. (2008). Educational stories in Islam and its applications in kindergartens (Concept of a Proposal), Unpublished Master Thesis, Umm Al-Qura University, Faculty of Education, Makkah.

Lafi, Saeed Abdullah. (2010). School activity between theory and practice. World of Books, Cairo.

Leahey, T.H. (1997). Learning and cognition(4th ed.). Prentice - Hall, Inc.

Martincevic, J. (2010). Extracurricular Activities as A Factor ofEducation for a Leisure Time. Zivot Skola, 24, 19- 34.

Miller, N. E., \& Dollard, J. (1941). Social Learning and Imitation. New Haven: Yale University Press.

Nahlawi, Abdul Rahman. (2004). The origins of Islamic education and its methods at home, school and society. Dar al-Fikr, Damascus.

Owais, Razan. (2009). Effectiveness of building a program to train kindergarten teachers to develop some cognitive skills in kindergarten children, unpublished $\mathrm{PhD}$ thesis, Faculty of Education, University of Damascus.

Piaget, J. (1972). The psychology of the child. New York: Basic Books.

Salameh Adel, Al-Khuraisat, Samir, Sawafta, Walid \& Al-Qatait, Ghassan. (2009). General Teaching methods: Contemporary Applications, Dar Al-Thaqafa for Publishing and Distribution, Jerash.

Spears, A., \& Wilson, L. (2005). Brain-based learning highlights File: A Brain-ased learning. $2 \mathrm{htm}$.

Wertheimer, M., King, D. B., Peckler, M. A., Raney, S., \& Schaef, R. W. (1992). Carl Jung and Max Wertheimer on a priority issue. Journal of the history of the behavioral sciences, 28(1), 45-56. https://doi.org/10.1002/1520-6696(199201)28:1\%3C45::AID-JHBS2300280104\%3E3.0 .CO;2-P 


\section{Macrothink}

\section{Copyright Disclaimer}

Copyright for this article is retained by the author(s), with first publication rights granted to the journal.

This is an open-access article distributed under the terms and conditions of the Creative Commons Attribution license (http://creativecommons.org/licenses/by/3.0/). 